\title{
The Brazil Reader
}

History, Culture, Politics

\section{Robert M. Levine and John J. Crocitti, editors}

With more than a hundred entries from a wealth of perspectivesThe Brazil Reader captures the scope of Brazil's rich diversity and distinction as no other book has done.

The Brazil Reader's historical selections range from early colonization to the present day, with sections on imperial and republican Brazil, the days of slavery, the Vargas years, and the more recent return to democracy. They include letters, photographs, interviews, legal documents, visual art, music, poetry, fiction, reminiscences, and scholarly analyses. They also include observations by ordinary residents, both urban and rural, as well as foreign visitors and experts on Brazil. Many pieces have been written or translated expressly for this volume.

544 pages, 60 illustrations, paper $\$ 21.95$

Latin America Readers
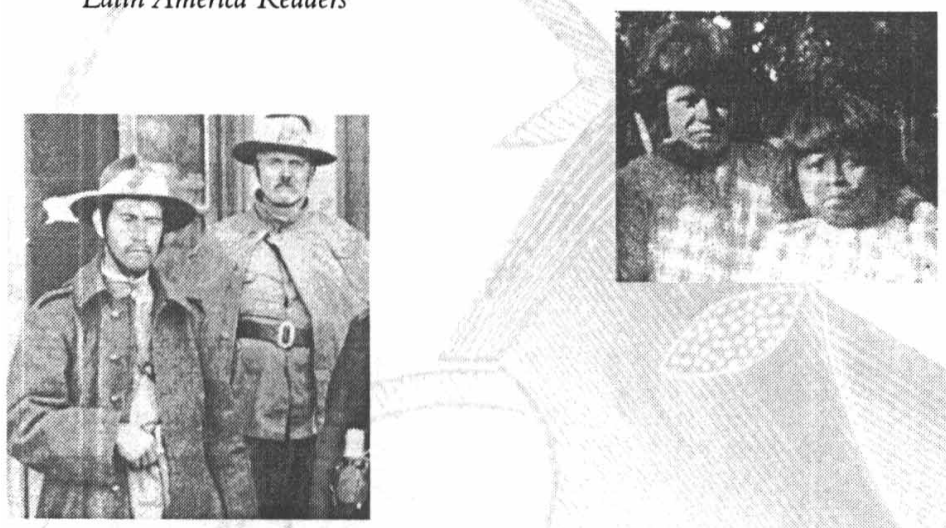

\section{Duke University Press}

Box 90660 Durham, NC 27708-0660 toll-free 1-888-651-0122

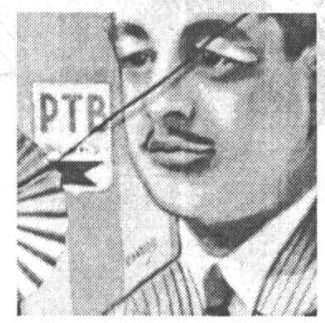




\section{Social}

\section{History}

\section{FROM DUKE}

High Tech and High

Heels in the Global

Economy

Women, Work, and

Pink-Collar Identities in

the Caribbean

Carla Freeman

384 pages, paper $\$ 18.95$

Imposing Decency

The Politics of Sexuality

and Race in Puerto Rico,

1870-1920

Eileen Suarez Findlay

320 pages, 15 b\&w photos,

paper $\$ 18.95$

American Encounters/

Global Interactions

Race. Place.

and Medicine

The Idea of the Tropics in

Nineteenth-Century Brazil

Julyan G. Peard

240 pages, paper $\$ 17.95$
In Defense of Honor

Sexual Morality, Modernity, and Nation in Early-

Twentieth-Century Brazil

Sueann Caulfield

320 pages, paper $\$ 19.95$

Inka Bodles and

the Body of Christ

Corpus Christi in Colonial

Cuzco, Peru

Carolyn Dean

264 pages, 51 illus., paper $\$ 18.95$

\section{A Colonial Lexicon}

Of Birth Ritual, Medicalization, and Mobility in the Congo

Nancy Rose Hunt

448 pages, 55 illus., paper $\$ 20.95$

Body, Commodity, Text

The Expectation of Justice

France, 1944-1946

Megan Koreman

344 pages, paper $\$ 18.95$

Revolution and

World Politics

The Rise and Fall of the

Sixth Great Power

Fred Halliday

416 pages, paper $\$ 19.95$

From East Germans

to Germans?

The New Postcommunist Elites

Jennifer A. Yoder

320 pages, 21 tables, paper $\$ 18.95$

\section{Duke University Press}

Box $90660 \cdot$ Durham, NC $27708-0660 \cdot$ toll-free 1-888-651-0122 


\section{Faculty Editors}

Joseph S. Alter, Anthropology, University of Pittsburgh

Paula Baker, History, University of Pittsburgh

Elizabeth Faue, History, Wayne State University

Cary Federman, Political Science, Duquesne University

Werner Troesken, History, University of Pittsburgh

\section{Graduate Student Editors}

Bernard G. Haggerty, History, University of Pittsburgh

R. Darrell Meadows, History, Carnegie Mellon University

David Recht, History, University of Pittsburgh

Jamie Sanders, History, University of Pittsburgh

Cathleen Schlegel, Sociology, University of Pittsburgh

Carl A. Zimring, History, Carnegie Mellon University

\section{Editorial Board}

Margo Anderson, History, University of Wisconsin-Milwaukee

Kathleen Blee, Women's Studies and Sociology, University of Pittsburgh

Charlotte Borst, History, St. Louis University

George Boyer, Industrial and Labor Relations, Cornell University

Ballard Campbell, History, Northeastern University

Elisabeth S. Clemens, Sociology, University of Arizona

Larry Goldsmith, History, Hiram College

Joanne Goodwin, History, University of Nevada, Las Vegas

Stephen Haber, History, Stanford University

John R. Hall, Sociology, University of California at Davis

Madeleine Hurd, History, University of Pittsburgh

Ann Jannetta, History, University of Pittsburgh

Kathleen Jones, History, Virginia Polytechnic Institute and State University

Bruce Laurie, History, University of Massachusetts at Amherst

Robert Lieberman, Political Science, Columbia University

Rick Maddox, Anthropology, Carnegie Mellon University

Robert Margo, Economics and Business Administration, Vanderbilt University

Leslie Page Moch, History, Michigan State University

Richard Niemi, Political Science, University of Rochester

Jeffrey K. Olick, Sociology, Columbia University

Kimberley Phillips, History, College of William and Mary

Peter Rachleff, History, Macalester College

Anton Rosenthal, History, University of Kansas

Andrew Rutten, Government, Cornell University

Harry Sanabria, Anthropology, University of Pittsburgh

Virginia Sapiro, Political Science, University of Wisconsin-Madison

Daniel Scott Smith, History, University of Illinois at Chicago

Charles Wetherell, History, University of California, Riverside

\section{SSHA Executive Director}

Erik Austin, Institute for Social Research, University of Michigan

\section{Editorial Assistant}

Mary S. Redd Magnotta, History, University of Pittsburgh 


\section{Latin}

\section{American}

\section{Social History}

\section{from Duke}

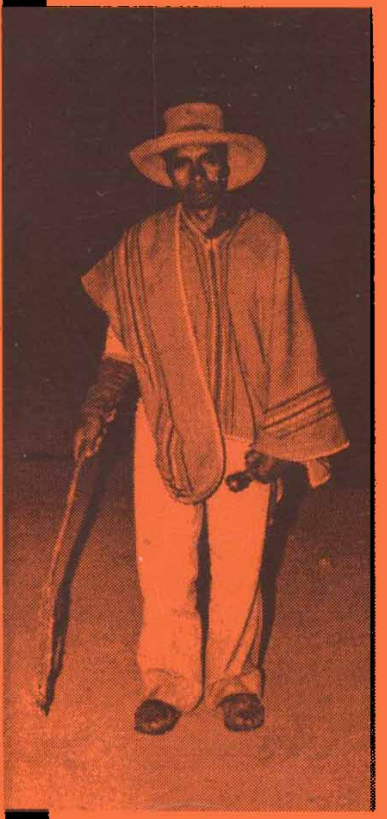

Duke University

\section{Press}

Box 90660

Durham, NC

27708-0660

toll-free 1-888-651-0122

www.duke.edu/web/

dupress/
Shining and Other Paths

War and Society in Peru, 1980-1995

Steve J. Stern, editor

552 pages, paper $\$ 21.95$

Latin America Otherwise

\section{The Brazil Reader}

History, Culture, Politics

Robert M. Levine and

John J. Crocitti, editors

576 pages, 60 illus., paper $\$ 21.95$

Latin America Readers

\section{Nightwatch}

The Politics of Protest in the Andes

Orin Starn

304 pages, 44 illus., paper $\$ 17.95$

Latin America Otherwise

\section{Identity and Struggle at the} Margins of the Nation-State The Laboring Peoples of Central America and the Hispanic Caribbean Aviva Chomsky and Aldo A. Lauria Santiago, editors 416 pages, paper $\$ 21.95$ Comparative and International Working-Class History

\section{Popular Movements} and State Formation in Revolutionary Mexico

The Agraristas and Cristeros

of Michoacán

Jennie Purnell

288 pages, paper $\$ 17.95$

\section{Colonial Habits}

Convents and the Spiritual

Economy of Cuzco, Peru

Kathryn Burns

296 pages, paper $\$ 17.95$ 